\title{
NEW MEANINGS FOR OLD KNOWLEDGE: THE PEOPLE'S BIODIVERSITY REGISTERS PROGRAM
}

\author{
Madhav Gadgil, ${ }^{1,2,4}$ P. R. Seshagiri Rao, ${ }^{1}$ G. Utkarsh,${ }^{1}$ P. Pramod,${ }^{2}$ Ashwini Chhatre, ${ }^{3}$ \\ AND Members of the People's Biodiversity Initiative \\ ${ }^{1}$ Centre for Ecological Sciences, Indian Institute of Science, Bangalore 560 012, India \\ ${ }^{2}$ Jawaharlal Nehru Centre for Advanced Scientific Research, Jakkur P.O., Bangalore 560 064, India \\ ${ }^{3}$ Navrachana, P. B. 31, Palampur, Himachal Pradesh, 176 061, India
}

Abstract. The program of People's Biodiversity Registers (PBR) is an attempt to promote folk ecological knowledge and wisdom in two ways: by devising more formal means for their maintenance, and by creating new contexts for their continued practice. PBRs document folk ecological knowledge and practices involving the use of natural resources, with the help of local educational institutions and NGOs working in collaboration with local, decentralized institutions of governance. During 1996-1998, 52 such documents were prepared from village clusters distributed in eight states and union territories representing a wide spectrum of ecological and social regimes of India. They reveal a picture of generally declining productivity and diversity of living resources outside of intensively managed ecosystems. There are, however, notable exceptions; two of our case studies provide examples of self-organized systems of management that have successfully protected, and indeed promoted, restoration of forest and wildlife resources. The PBRs also indicate a widespread erosion of practical ecological knowledge and of traditions of sustainable use and conservation. This is linked to the fact that those most intimately dependent on and knowledgeable about biodiversity belong to the economically and politically most disadvantaged segments of the society. In consequence, conservation and sustainable use of biodiversity are not a high priority among the development aspirations held by the people. Nevertheless, people are concerned about degradation of the base of living resources and offer a number of concrete suggestions on their management. In fact, in a few cases, the PBR exercises have encouraged people to put such measures for more prudent use of local biodiversity resources into practice. The process of preparation of PBRs, as well as the resultant documents, could serve a significant role in promoting more sustainable, flexible, participatory systems of management and in ensuring a better flow of benefits from economic use of the living resources to the local communities.

Key words: adaptive co-management; benefit sharing; CBD; conservation priorities; development aspirations; folk knowledge; India; Peoples's Biodiversity Registers; Traditional Ecological Knowledge.

\section{INTRODUCTION}

All knowledge and wisdom ultimately flow from practices, but their organization differs among the different streams of knowledge. Folk knowledge is maintained, transmitted, and augmented almost entirely in the course of applying it in practice; it lacks a formal, institutionalized process for handling. Folk ecological knowledge and wisdom are therefore highly sensitive to changing relationships between people and their ecological resource base. Today, both are eroding at a fast pace for two reasons: firstly, people now have access to newer resources such as modern medicines and are no longer as dependent on local medicinal plants and animals as before; and secondly, people are increas-

Manuscript received 20 January 1998; revised 22 March 1999; accepted 26 March 1999; final version received 5 May 1999. For reprints of this Invited Feature, see footnote 1, p. 1249

${ }^{4}$ E-mail: madhav@ces.iisc.ernet.in ingly losing control over the local resource base, with takeovers by state and corporate interests (Gadgil and Berkes 1991). However, folk knowledge and wisdom, with their detailed locality- and time-specific content, are of value in many contexts. They must therefore be supported in two ways: by creating more formal institutions for their maintenance and, most importantly, by creating new contexts for their continued practice (Gadgil et al. 1993). The program of "People's Biodiversity Registers"' (PBR) is such an attempt.

It is a program of documenting how lay people, primarily rural and forest-dwelling communities, understand living organisms and their ecological setting. The information recorded relates to present status as well as changes over recent years in distribution and abundance; factors affecting distribution and abundance, including habitat transformations and harvests; known uses; and economic transactions involving these organisms. The document also records the perceptions of 
local people about ongoing ecological changes, their own development aspirations, and their preferences as to how they would like the living resources and habitats to be managed. We summarize here our experience of developing the concept and organizing the preparation of 52 such PBRs in different parts of India, the resultant understanding, and the interest that this program has generated (Gadgil et al. 1998).

We believe that the PBR process, involving a collaboration between people working in the organized sector (e.g., educational institutions, government agencies, and NGOs) and the practical ecologists, peasants, herders, fishers, and traditional healers (all in the unorganized sector), is as significant as the product: the recorded information. A subset of the information collected, especially that pertaining to medicinal and other economic uses, has been recorded by ethnobiologists working in academic institutions and for the pharmaceutical industry and other commercial interests (Reid et al. 1993, Martin 1995). In this process, however, the local people are treated as anonymous informants; they receive no particular credit for their knowledge, and the information is accumulated with little reference to particular localities and times (Posey and Dutfield 1996). The PBR process, on the other hand, aims to record the information with full acknowledgment of the source; it thereby serves as a possible means of sharing of benefits that may flow from further economic utilization of such information. Another subset of the information recorded in PBRs is collected during "Participatory Rural Appraisal" (PRA) exercises (Chambers 1992,1993$)$ that feed into decentralized development planning. Generating good information for such participatory development is also an objective of PBRs; the PBRs differ from PRAs in their greater emphasis on recording all pertinent knowledge, including changes over the recent past, and in giving specific credit for the information collected. Although we have so far completed only one round of PBRs in any one locality, we expect it eventually to become an ongoing process of monitoring ecological change and generating the necessary information for locally adaptive management of living resources.

\section{Materials And Methods}

The People's Biodiversity Register Programme was initiated by the Foundation for Revitalization of Local Health Traditions as a program focused on documenting community-based knowledge of medicinal plants and their uses, through a workshop held at the Indian Institute of Science, Bangalore in April 1995 (Gadgil et al. 1996). Workers from voluntary agencies participating in this workshop went on to compile, by mid1996, what were termed Community Biodiversity Registers at 24 sites distributed over 10 states of India. This experience suggested that it would be desirable to broaden the scope of the exercise to all elements of biodiversity, and to record knowledge and perceptions at all levels, from individuals, households, and ethnic groups to multiethnic communities. Thus, name of the program was modified to People's Biodiversity Register. A second workshop to explore this broader approach was organized at Supegaon in Maharashtra in August 1995. This was followed by initiation of PBR activities at 10 sites in four states of the Western Ghats region, as a part of the Western Ghats Biodiversity Network Programme (Gadgil 1996). These experiences laid the foundation of the current set of PBR preparation at 52 sites in eight states as a part of the Biodiversity Conservation Prioritization Programme of the World Wide Fund for Nature-India (Gadgil et al. 1998). The focus of this program is on the conservation priorities and preferred strategies of the local people. The account that follows primarily refers to the third phase.

This program was initiated through a workshop held in March 1996 at the Indian Institute of Science, Bangalore, involving potential collaborators from the states of Himachal Pradesh, Rajasthan, Bihar, Assam, Orissa, Karnataka, Maharashtra, and the Union Territory of Andaman and Nicobar Islands. These eight regions were selected to provide a good sample of the varied ecological and social regimes of the subcontinent. Discussions at this workshop permitted a crystallization of the methodology and drafting of a methodology manual termed Srishtigyan (Hindi: Srishti, nature; Gyan, knowledge). There followed a series of further training programs and workshops that have facilitated the fieldwork spread over 52 sites throughout the subcontinent, employing a common methodology. The first task of the state-level coordinators was to select the individual study sites that would represent the entire spectrum of ecological and social regimes within the state (Fig. 1 and Table 1). The 52 study localities cover all of the bioclimatic zones of the country (Gadgil and Meher-Homji 1990): tropical wet (18 sites), tropical moist (16), tropical dry (6), tropical semiarid (4), subtropical (4), temperate (3), and alpine (1). They also cover a whole range of ecosystem types: forest (30), pastures (8), wetlands (14), degraded forests (3), agriculture (33), horticulture (8), and deserts (3). Sixteen of the study areas are protected: six national parks and 10 wildlife sanctuaries, three of which are tiger reserves and two are bird sanctuaries.

After study areas were selected, field investigators were chosen from among college- or university-level science teachers or workers of rural development or environment-oriented NGOs. Many of these people are from nearby localities, and have considerable previous familiarity with the study sites. The field investigating teams worked closely with, and often included, some of the local residents. Of the 52 principal investigators of the program, 14 were college teachers, two university teachers, and two school teachers. There were four 


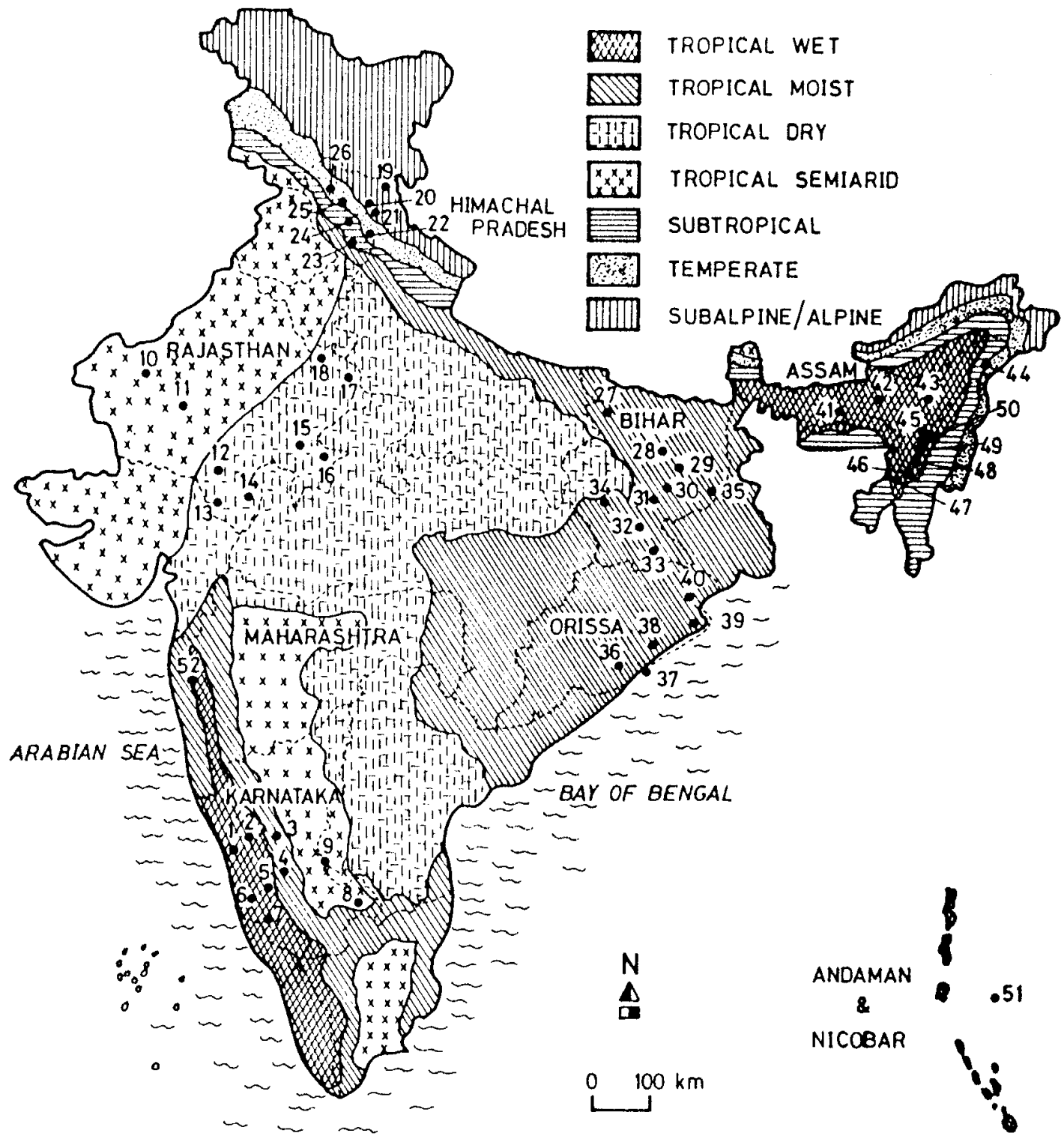

FIG. 1. Distribution of study sites across various bioclimatic zones in India. Site numbers refer to those in Table 1 .

government officials, 13 NGO workers, and six individuals engaged in development activities on their own. The entire program engaged 350 researchers from all of these sectors and 200 assistants from village communities. As many as 1000 villagers had extensive involvement in the program as local knowledgeable individuals.

The methodology of field investigations included the following components: building rapport with local people, clarifying project rationale and obtaining local approval for the joint studies, identifying different biodiversity user groups, identifying individuals knowledgeable in different aspects of distribution and uses of biodiversity, interviewing individuals and groups with members representing different user groups, mapping the study site landscape, visiting representative elements of this landscape with some user-group members and knowledgeable individuals, discussing resource use at the study area with the entire village assembly and with outsiders such as nomadic shepherds or artisans, traders, and government officials. This methodology is spelled out in detail in the Srishtigyan manual (Chhatre et al. 1998).

\section{RESUlts}

\section{Living resources}

Many widespread trends are evident in the 52 PBRs representing the entire spectrum of ecoclimatic and so- 
TABLE 1. Location, environmental setting, and names and affiliations of the investigators at each study site in India. Code numbers correspond to the site numbers in Fig. 1.

\begin{tabular}{|c|c|c|c|c|c|c|}
\hline Code & Region/village & $\mathrm{BCZ} \dagger$ & Ecosystems $\ddagger$ & $\mathrm{PA} \S$ & Team\| & Principal investigator \\
\hline \multicolumn{7}{|c|}{ Karnataka State } \\
\hline 1 & Holanagadde & TW & $\mathrm{C}$ & & $\mathrm{C}$ & Prakash Pandit, H. M. Ganapathi \\
\hline 2 & Kalase & TW & $\mathrm{F}$ & & $\mathrm{C}$ & Dayanand Bhat \\
\hline 3 & Kamadhodu & TW & A & & $\mathrm{S}$ & Mahesh Gowda, T. S. Channesh \\
\hline 4 & Neralekoppa & TM & $\mathrm{F}, \mathrm{A}, \mathrm{H}$ & & $\mathrm{C}$ & C. K. Poojari \\
\hline 5 & Kigga & TW & $\mathrm{F}, \mathrm{A}, \mathrm{H}$ & NP & $\mathrm{C}$ & G. K. Bhatta, P. Bhat \\
\hline 6 & Mala & TW & $\mathrm{F}, \mathrm{A}, \mathrm{H}$ & NP & $\mathrm{C}$ & K. P. Achar \\
\hline 7 & Subramanya & TW & $\mathrm{F}, \mathrm{A}, \mathrm{H}$ & & $\mathrm{C}$ & K. N. Deviprasad \\
\hline 8 & Gandlahalli & TS & A & & I & Amar Prasad, T. S. Channesh \\
\hline 9 & Chennekeshavapura & TS & $\mathrm{A}, \mathrm{P}$ & & I & P. R. Sheshagiri Rao \\
\hline \multicolumn{7}{|c|}{ Rajasthan State } \\
\hline 10 & Vrimdeora & TS & $\mathrm{D}$ & & $\mathrm{N}$ & Hukum Singh Rajpurohit \\
\hline 11 & Doli & $\mathrm{TS}$ & $\mathrm{D}$ & & $\mathrm{N}$ & Sudhir Mathur \\
\hline 12 & Bichiwara & TD & DF & & $\mathrm{N}$ & Kavitha Gandhi, Mamta Bardhan \\
\hline 13 & Mahad & TD & $\mathrm{F}, \mathrm{A}$ & WS & $\mathrm{N}$ & Soumitri Das, Niraj Kumar Negi \\
\hline 14 & Kewara & $\mathrm{TD}$ & $\mathrm{F}, \mathrm{A}$ & & $\mathrm{C}$ & R. K. Garg \\
\hline 15 & Devli & TD & $\mathrm{R}, \mathrm{A}$ & & $\mathrm{N}, \mathrm{C}$ & K. K. Dadhich \\
\hline 16 & Dhikonia & TD & DF,A & & $\mathrm{N}, \mathrm{C}$ & Prahlad Dubey \\
\hline 17 & Aghapur & TD & $\mathrm{W}$ & & $\mathrm{C}$ & S. S. Jain \\
\hline 18 & Mathurawat & TD & $\mathrm{F}$ & & $\mathrm{N}$ & Manpal Singh \\
\hline \multicolumn{7}{|c|}{ Himachal Pradesh State } \\
\hline 19 & Shgnam & A & $\mathrm{D}$ & & I & Chhewand Dorjezanpo \\
\hline 20 & Shainshar & $\mathrm{T}$ & $\mathrm{F}, \mathrm{P}$ & NP & $\mathrm{N}$ & Pawan Sharma, Joginder Negi \\
\hline 21 & Karsog & $\mathrm{T}$ & $\mathrm{F}, \mathrm{P}$ & & I & Nek Ram Sharma \\
\hline 22 & Kathog & $\mathrm{T}$ & $\mathrm{F}, \mathrm{P}, \mathrm{H}$ & & $\mathrm{N}$ & G. Thakar, N. Thaltokhod \\
\hline 23 & Darlaghat & $\mathrm{S}$ & $\mathrm{F}, \mathrm{P}, \mathrm{A}, \mathrm{H}$ & & $\mathrm{N}$ & Des Raj, Hema Sharma \\
\hline 24 & Kaihad & $\mathrm{S}$ & $\mathrm{F}, \mathrm{P}, \mathrm{A}$ & & $\mathrm{N}$ & Gauri Datta, Naval Kishore \\
\hline 25 & Rajai & $\mathrm{S}$ & $\mathrm{F}, \mathrm{P}, \mathrm{H}$ & & I & Pameen Kotoch, Narendra Kumar \\
\hline 26 & Banet & $\mathrm{S}$ & $\mathrm{F}, \mathrm{P}, \mathrm{H}$ & & I & Man Singh Kapoor \\
\hline \multicolumn{7}{|c|}{ Bihar State } \\
\hline 27 & Udaipur & TM & $\mathrm{W}, \mathrm{A}$ & WS & $\mathrm{C}, \mathrm{N}$ & Ashwini Kumar \\
\hline 28 & Kabar Lake & TM & W,A & WS(B) & $\mathrm{C}, \mathrm{N}$ & Shankar Kumar, A. K. Mishra \\
\hline 29 & Bhimandh & TM & $\mathrm{W}, \mathrm{F}$ & WS & $\mathrm{C}$ & Pankaj Kumar, B. R. Sinha \\
\hline 30 & Hazaribag & TM & $\mathrm{F}, \mathrm{A}$ & WS & $\mathrm{N}, \mathrm{G}$ & Pankaj Srivastava \\
\hline 31 & Ranchi Town & TM & $\mathrm{F}, \mathrm{A}$ & & $\mathrm{C}, \mathrm{N}$ & B. K. Sinha, A. K. Sinha \\
\hline 32 & Dalma & TM & $\mathrm{F}, \mathrm{A}$ & WS & $\mathrm{N}, \mathrm{G}$ & D. S. Srivastava \\
\hline 33 & Saranda & TM & $\mathrm{F}, \mathrm{A}$ & & $\mathrm{C}, \mathrm{N}$ & Sulaiman Quli \\
\hline 34 & Palamu & TM & $\mathrm{F}, \mathrm{A}$ & $\mathrm{NP}(\mathrm{TR})$ & $\mathrm{N}, \mathrm{G}$ & D. S. Srivastava \\
\hline 35 & Udhwa Lake & $\mathrm{TM}$ & $\mathrm{W}, \mathrm{A}$ & & $\mathrm{N}, \mathrm{G}$ & Pankaj Srivastava \\
\hline \multicolumn{7}{|c|}{ Orrisa State } \\
\hline 36 & Krushnanagar & TM & DF,A & & $\mathrm{N}$ & Ashok Kumar Nayak \\
\hline 37 & Berhampore & TM & $\mathrm{W}, \mathrm{A}$ & WS & $\mathrm{N}$ & Manas Mishra \\
\hline 38 & Dhani & TM & $\mathrm{F}, \mathrm{A}$ & & $\mathrm{N}$ & Rekha Panigarhi, Y. Giri Rao \\
\hline 39 & Bhitarkanika & TM & W,A & WS & $\mathrm{N}$ & Rekha Panigarhi \\
\hline 40 & Simlipal & $\mathrm{TM}$ & $\mathrm{F}, \mathrm{A}$ & $\mathrm{NP}(\mathrm{TR})$ & $\mathrm{N}$ & Sanjeev Padhi \\
\hline \multicolumn{7}{|c|}{ Assam State } \\
\hline 41 & Rani-Garbhanga & TW & $\mathrm{F}, \mathrm{A}, \mathrm{W}$ & & $\mathrm{U}$ & Mahendra Boro, Rathin Barman \\
\hline 42 & Nameri & TW & $\mathrm{F}, \mathrm{A}, \mathrm{W}$ & WS & $\mathrm{U}$ & R. K. Das, Bebeka Bora, Talukdar \\
\hline 43 & Majoli & TW & W,A & & $\mathrm{U}, \mathrm{C}$ & Debojit Baruah, Anand Hazarika \\
\hline 44 & Dibru-Saikhowa & TW & $\mathrm{F}, \mathrm{A}, \mathrm{W}$ & WS & $\mathrm{G}, \mathrm{U}$ & Narayan Ssharma, R. Barman \\
\hline 45 & Lamding & TW & $\mathrm{F}$ & & $\mathrm{U}, \mathrm{C}$ & Joshedev Arjun \\
\hline 46 & Sone Beel & TW & W,A & & U,N,S & D. Kar, G. K. Das, M. Purkayastha \\
\hline 47 & Sat Beel & TW & W,A & & $\mathrm{U}, \mathrm{N}$ & M. H. Burbhuia \\
\hline 48 & Loharband & TW & $\mathrm{F}, \mathrm{A}$ & & $\mathrm{U}, \mathrm{N}$ & Ranajit Das \\
\hline 49 & Bhuban Hill & TW & $\mathrm{F}$ & & U,N & D. Saha \\
\hline 50 & Haflong & TW & $\mathrm{F}$ & & $\mathrm{N}$ & R. A. Laskar, S. Thoasen \\
\hline \multicolumn{7}{|c|}{ Andaman } \\
\hline 51 & Rangat & TW & $\mathrm{F}, \mathrm{A}$ & & $\mathrm{N}$ & A. Chakraborty, Sameer Acharya \\
\hline \multicolumn{7}{|c|}{ Maharashtra } \\
\hline 52 & Shilimb & TM & $\mathrm{F}, \mathrm{A}, \mathrm{P}$ & & I & Smita Botre \\
\hline
\end{tabular}


cioeconomic conditions of this diverse country. Agricultural production, especially of cereal grains, has increased over India as a whole, as has the production of wood from eucalyptus, poplar, and Acacia auriculiformis plantations. Fish and shrimp production has also increased under aquaculture. These increases result from intensification of inputs and management. Outside such managed ecosystems, however, there has been widespread decline in both productivity and diversity of living resources. Such decline can be traced to a variety of factors: breakdown of social regulation of harvesting regimes; escalation in demand, well beyond the productive capacity of the resources, for meeting subsistence and market demands; deterioration in the productive capacity of resources attributed to adverse environmental changes such as pollution and siltation; and diversion of the land to other purposes such as mining and road construction.

We may cite here two examples of the breakdown in social regulation, one related to a breakdown of community-level understanding, and the other to a breakdown of localized authority. First, along several streams in the mountainous state of Himachal Pradesh, people used to observe a system of sacred pools called machiyals, where no fishing was permitted. This system of refugia promoted long-term persistence of fish populations fished elsewhere along the stream (Gokhale et al. 1998). Establishment of road communications has now rendered many parts of the state accessible to outsiders, such as military personnel who do not respect the protection to the machiyals. Simultaneously, road construction activity has led to widespread availability of dynamite, which is used for highly destructive fishing by such outsiders. This has led to considerable depletion of fish populations along these streams.

The second example comes from the semiarid and arid state of Rajasthan, where extensive areas adjacent to villages were protected as sacred groves or orans, subject to highly regulated harvests, primarily of dead wood and fodder. These regulations were enforced by the village landlord families, mostly belonging to the dominant Rajput castes, until the land reforms around 1970. The orans were taken over as government property during land reforms. However, the government machinery did not act as an effective regulatory authority, so that most orans have become open-access resources subject to unregulated harvests, except for special cases such as Doli, which will be discussed.

Examples of excessive levels of harvests depleting already dwindling living resources of the public lands are part of every one of the PBRs. Resources so depleted include fuelwood, grazing, small timber for house construction, grass and palm leaves for thatching roofs, and medicinal plants. One village in Rajasthan was earlier named Vaidyonki Devli, Devli village of medicine men. With the depletion of all natural vegetation, including the medicinal plant resources, the villagers have removed the epithet Vaidyonki from the village name. The state of Himachal Pradesh has also witnessed a rapid depletion of medicinal plant resources with the manifold increase in commercial demand, for instance, for leaves of Taxus buccata, now known to contain an anti-cancer compound.

Living resources have declined through pollution. For example, several villages in Himachal Pradesh report the loss of honeybees, important for crop pollination, due to pesticide use. Fish populations of the large water body of Sone Beel in the Barak Valley of Assam have reportedly declined due to siltation following construction of a dam. Habitat change is another significant factors. In the village of Holanagadde in Karnataka, medicinal plant resources declined when the natural scrub created by lopping for fuelwood was replaced by an Acacia auriculiformis plantation.

The governmental agencies that control the public land and water resources more and more tightly have responded to this erosion of living resources by further restricting people's access without being equally effective in restricting the access of well-organized commercial interests. Thus, access to the Bharatpur National Park by Aghapur villagers has been strongly restricted, whereas the Darlaghat Wildlife Sanctuary in Himachal Pradesh was delisted to facilitate the creation of cement plants.

Our PBRs do not, however, merely record instances of the degradation of living resources of public lands and waters. Two of the PBRs, pertaining to Doli village in Rajasthan and Dhani village in Orissa, record examples of the spontaneous establishment of regimes of regulated use, leading to resource recovery. The restrictions in Doli are the result of religious sentiments of a Hindu sect, the Bishnois, whose precepts call for protection of several species of plants and animals. At their instance, the local sacred grove (oran) has been well protected over the last 25 years (Gokhale et al. 1998). In the primarily tribal village of Dhani, the people on their own initiative have established a forest protection committee and have ensured excellent natural regeneration of the forest. We will discuss the Dhani experience further.

\section{Practical ecological knowledge}

People's dependence on living resources has declined along with the decline in ready availability of such resources to them. At the same time, people have access to new resources that can substitute, e.g., allopathic drugs in place of herbal remedies, tiles in place of thatching for roof, or synthetic dyes in place of vegetable dyes. This has led to a decline in interest, among the younger geneation, in the knowledge of living resources, a decline reinforced by the modern, largely bookish system of education. Our PBR studies reflect such decline in knowledge. In Kaihad village in Himachal Pradesh, residents as a whole know of $\sim 450$ 
TABLE 2. Distribution of knowledge of a variety of specific uses of 173 plant species among different human communities of Shilimb village in Maharashtra State, India.

\begin{tabular}{|c|c|c|c|c|c|}
\hline \multirow[b]{2}{*}{ Kind of uses } & \multicolumn{2}{|c|}{ Communities } & \multirow[b]{2}{*}{$\begin{array}{l}\text { Kat- } \\
\text { karis }\end{array}$} & \multirow[b]{2}{*}{$\begin{array}{c}\text { Dhan- } \\
\text { gars }\end{array}$} & \multirow[b]{2}{*}{$\begin{array}{l}\text { Brah- } \\
\text { mins }\end{array}$} \\
\hline & All 13 & $\begin{array}{c}\text { At } \\
\text { least } \\
10\end{array}$ & & & \\
\hline Human medicine & 2 & 9 & 57 & 16 & 9 \\
\hline Veterinary medicine & 1 & 1 & 1 & 3 & 1 \\
\hline Food & 45 & 46 & 56 & 49 & 45 \\
\hline Fodder (cattle) & 0 & 0 & 0 & 5 & 0 \\
\hline Fodder (sheep) & 0 & 0 & 0 & 4 & 0 \\
\hline Agricultural implements & 2 & 13 & 8 & 13 & 13 \\
\hline Ropes & 3 & 4 & 4 & 4 & 4 \\
\hline Fuelwood & 4 & 4 & 4 & 4 & 4 \\
\hline Fish poison & 0 & 0 & 4 & 0 & 0 \\
\hline Other commercial uses & 0 & 1 & 7 & 1 & 1 \\
\hline
\end{tabular}

Note: Table entries are numbers of plant species.

species of plants and animals. However, while those 50 years or older can identify $\sim 70 \%$ of local flowering plants, characterize $40 \%$, and mention uses for $5 \%$, the respective percentages decline to $25 \%, 4 \%$, and $1 \%$ among people $30-50$ years old, and to $0 \%$ among younger people.

This is not universal, however. In predominantly fishing communities, such as Berhampur village near Chilika Lake in Orissa, much ecological knowledge persists among youth who continue to be engaged in fishing as a profession. Similarly, knowledge and use of medicinal plants is still common among all sections of the population, including the youth, in Mala village in Karnataka.

\section{People affected}

The starting point of the PBR exercise is to classify the concerned human population into "user groups" on the basis of their relation to natural, particularly, living, resources. Thus, cultivators owning sufficiently large tracts of land to fulfill their household biomass requirements may constitute one group; landless agricultural laborers dependent on public lands for their biomass requirements, such as fuelwood or dung, and on weaving baskets or mats for employment in the nonagricultural season, may constitute a second group, and specialist herders a third group. Within households, women assume greater responsibility for fuel and fodder collection than men; hence, women from poor, landless families may constitute a distinct user group. PBRs show that greater dependence on living resources is also accompanied by much greater knowledge. For instance, in Shilimb village in Maharashtra, 13 distinct endogamous groups fall into five major user groups. Brahmins are substantial landowners and traders, Katkaris are landless agricultural laborers, Dhangars are specialist herders, and the other 10 endogamous groups are divided into cultivators with medium-sized holdings and artisans. As Table 2 shows, Katkaris are by far more knowledgeable about uses of plant species. As may be expected, they are also reported to be the user group to suffer most from a degradation of the living resources of Shilimb. Similarly disadvantaged user groups are susceptible everywhere to suffering most from greater loss of access to public lands and water. For instance, similar groups in several PBR sites from Palamu National Park in Bihar are currently being asked to move out of their century-old settlement sites within forest areas.

\section{Motivation}

The PBR exercise involved recording the development aspirations of all of the different user groups at different sites. The citizens of India today uniformly equate development with higher incomes and upward social mobility. Everywhere, the wealthy and the powerful have better access to transport and communication, health care, education, and water for household use and irrigation; all segments of society aspire for enhanced access to these resources as the core of development. In contrast, the people most dependent on and knowledgeable about biodiversity are, without exception, the poorest and least powerful. Better access to biodiversity resources and their conservation therefore tend to be viewed as (no doubt) desirable, but certainly not an integral component of development aspirations. Almost no segment of the rural population today is strongly motivated to organize and participate in efforts at conservation and sustainable use of biodiversity.

The PBRs also record the perceptions of the rural population about the current role and motivation of other major agents influencing the living resources, namely government agencies such as forest departments, and traders and industry. The government agencies are reported as being self-serving, corrupt, and inefficient, the commercial interests as being motivated to pursue short-term profits. None of these agents are reported to be motivated to promote long-term conservation and sustainable-use objectives.

\section{Resultant conflicts}

PBRs document that almost all segments of the society in all study sites are committed to utilizing living resources in their own, often very divergent, short-term interests. This results in a variety of conflicts at many levels. A sample of conflicts recorded in the PBRs of Himachal Pradesh follows: (1) Within households, men and women differ on household use vs. marketing of wood, and therefore in the choice of species to be planted on public lands. (2) Within a village, different user groups differ on the desirability of maintaining grazing lands for livestock vs. planting these lands with trees that produce leaf fodder. (3) Within a village, the landless households would like some of the public lands to be made available to them for cultivation, whereas 
land-holding user groups would like them to be retained for fuelwood or fodder plantations or grazing lands. (4) There are conflicts among neighboring villages on access to fuelwood and grazing and on the level of protection to be offered to plantations. (5) Villagers settled permanently on land come in conflict with nomadic herders on access to grazing and fodder. (6) Villagers come in conflict with traders in the collection of medicinal plants. (7) Villagers are in conflict with industry over the mining of limestone from forest lands traditionally managed by villagers. (8) Villagers are in conflict with the forest department over control of land earlier regarded as village common lands, over demands for compensation for damage to crops by wildlife, and over management of village forest committees. (9) Villagers are also in conflict with the Public Works Department on damages suffered during road construction.

\section{Lessons learned}

PBRs include a discussion with the different user groups and with the village assembly as a whole on their prescriptions as to how the living resources should be managed. Although, as previously noted, the villagers do not include programs for conservation and sustainable use of these resources as a part of their development aspirations, they uniformly note their unhappiness at the deterioration of this resource base. Their prescriptions for its good management overwhelmingly call for empowerment of local communities to play this role. They are, however, clear that local communities cannot on their own shoulder the responsibility; they need to be supported in many ways. Such support is needed to resolve conflicts within the village society, with neighboring villages, and with commercial interests and the government agencies. All PBRs therefore suggest the institution of some form of comanagement, co-operative arrangements among villagers, local educational institutions, NGOs, and government agencies. There is considerable variation from user groups, from village to village, and from one part of the country to the other, in the form of the suggested institutions.

\section{Designing institutions}

Given the broad consensus on the desirability of organizing community-based management systems, the various suggestions are best examined in the context of Ostrom's $(1990,1992)$ seven principles of design of long-enduring, self-organized systems. Clearly, it is not feasible to establish fully autonomous, self-organized systems on any widespread scale in the present-day Indian context (Gokhale et al. 1998). That is why the PBRs call for systems of co-management involving substantial support by government agencies to the community-based institutions as the appropriate arrangement (Gadgil and Rao 1995). Ostrom's principles pro- vide useful pointers to the most important areas in which local communities need to be supported by the state apparatus and other agencies, such as educational institutions and NGOs, to create viable decentralized institutions of management of natural resources.

Principle I.-Boundaries of the managed resource should be well defined, and such a resource should be under the reasonably secure control of a well-defined human group.

At present, the living resources on public lands and waters are under the control of state agencies with boundaries defined by a system of land settlement as revenue lands, reserve forests, irrigation tanks, and so on. However, the state agencies have a far from secure control over these resources, many of which are subject to abuse as open-access resources. In their stead, a new, decentralized system of governance called Panchayat Raj, with elected representatives from the level of village councils upward, is being put in place all over India (Singh 1994). Many user groups support such an alternative arrangement; others express some doubts as to its efficacy. The unwillingness of government agencies to give up their own powers and to place resources under the secure control of Panchayat Raj institutions seems to be a major difficulty. Other problems arise in the case of fugitive resources, e.g., river water affected by upstream influences such as water withdrawal or pollution. PBRs emphasize the need to set up proper machinery to resolve such cross-border conflicts.

Principle II.-Groups responsible for resource management should be effectively organized.

Our PBRs record several misgivings about the efficacy of Panchayat Raj institutions to manage the living resources of public lands and waters. In part, these relate to the large number of people, on the order of 10000 , within the boundary of a panchayat. Self-organized management institutions are much more effective when they involve smaller, more homogeneous groups in face-to-face contact. Therefore, people in many of the study localities suggest that parallel committees representing smaller groups, working as subsidiary bodies of Panchayat Raj institutions, are more appropriate to take on tasks of natural resource management.

Principle III.-Long-term benefits of conservation measures should be commensurate with the costs incurred.

Conservation measures entail certain restraints on the immediate use of resources, or on conversion of the land or water areas to alternative uses. These would imply certain opportunity costs. Conservation measures may also entail other costs such as crop depredation and killing of livestock or even of people by wild animals. These costs need to be effectively offset by benefits, which would generally be realized in the longer term. Furthermore, the costs would not be borne, nor would the benefits flow, equally to the different 
user groups. Management needs to be tailored to the time, locality, and society-specific conditions. The PBRs bring this out well. For example, Himachal Pradesh sites might require rather special arrangements with nomadic herders who visit annually; these are irrelevant to other sites. Even with such flexible arrangements, the benefits may not be adequate to offset costs. Many PBRs therefore propose additional benefits, in the form of either social recognition or financial incentives. Thus, the village Doli in Rajasthan, which protects a large sacred grove with a substantial population of antelopes that inflict much damage on crops, may deserve payment of an annual service charge in recognition of its contribution to nature conservation. Such a service charge may take the form of a special annual grant by the Rajasthan State Government to the village council concerned.

Principle IV.-Machinery enforcing the observance of management rules should be accountable to, and respected by, the actors.

Government agencies such as the Forest Department today are in charge of monitoring observance of resource use regulations, except in a few special cases such as the Doli village in Rajasthan. All of our PBRs suggest that this machinery is viewed to be self-serving, corrupt and inefficient, in no way accountable to people. Suggested alternatives include committees of local people working with a transparently functioning, and people-oriented government machinery, assisted by local educational institutions and NGOs.

Principle V.-Agreements should be arrived at on the basis of collective choice.

Currently, the resource use prescriptions are imposed from outside by a government apparatus that has no accountability toward local communities. All of our PBRs propose that this be replaced by a process in which the local community is actively involved in consultation with concerned government agencies and other actors such as educational institutions.

Principle VI.-The management rules should be flexible.

Principle VII.- Sanctions against those violating the rules should be imposed in a graduated fashion.

The centralized management agencies tend to impose uniform and rigid rules and sanctions against violations. All of our PBR exercises point to the need for flexibility and fine-tuning to the specific situation. An excellent example of this is provided by the working of the Forest Protection Committee formed at the initiative of people from a cluster of five villages around Dhani in Nayagarh district of Orissa. This management system was initiated in 1986 in response to extensive degradation of forest stock under government management. To begin with, the Forest Protection Committee banned all collection of forest produce, as well as grazing and encroachment for cultivation, in the 800-ha plot. Initially, fines for violation were collected on the basis of the kind of produce extracted. After two years of strict protection, the forest began to regenerate and the Forest Protection Committee decided to permit extraction of leaves and fruits and grazing by livestock. After a further period of regeneration, there was further relaxation, permitting collection of fuelwood for household needs, but without any felling of green trees. At the same time, a few of the poorest families are now allowed to collect a limited quantity of fuelwood for sale as well.

\section{Adaptive Co-MAnagement}

The very broad consensus from our PBR exercises is the need to establish community-based systems of resource management supported by, and working in collaboration with, concerned governmental agencies, educational institutions, and where appropriate, NGOs. There is also a clear endorsement of the need for these management systems to be flexible and tailored to specific situations. Such systems may be termed as systems of adaptive co-management (Walters and Hilborn 1976). The process of preparation of PBRs, as well as the product (the record created), emerge as very useful devices in such adaptive co-management systems (Anonymous 1996). The value of the PBR process is exemplified by an experience in the village Nanj from the Karsog study area of Himachal Pradesh. The village was an active participant in the literacy movement during 1992-1993 and the people were exposed to a variety of issues relating to natural resource management. As a consequence, there was consensus to enclose a heavily degraded patch of forest. Regeneration on this patch has been extremely promising. During the literacy campaign, a blackboard was painted on a wall at a public place in the village for open classes and dissemination of information. Over the last few years, it had fallen into disuse, but it was revived during the PBR documentation to display the information collected, leading to public debates on the issues and, in turn, to conservation actions.

One such debate centered around the species kambal (Rhus wallichi, Hook. f.), a multipurpose tree found up to the mid-Himalayas, considered to be a good source of fuelwood and green manure. It was pointed, using the blackboard, that excessive pressure of both fuelwood and manure collection had reduced the kambal to a bush in the forest, leading to declining availability of both fuelwood and manure. After many days of discussion in front of the blackboard, it was decided that leaf manure for ginger was a higher priority. As other fuelwood species were available in the forest, it was agreed to restrict the extraction of kambal to leaves for green manure, with bushes pruned in such a way that one or two shoots would be permitted to grow. At the same time, a few progressive farmers decided to experiment with agricultural crop residues as a substitute for kambal leaves for manure. Over one year, they dem- 
TABLE 3. Conservation issues and measures identified as possible solutions by fisherfolk of Chilika Lake in Orissa State, India.

\begin{tabular}{ll}
\hline \hline \multicolumn{1}{c}{ Issues } & \multicolumn{1}{c}{ Measures } \\
\hline Siltation & Dredging of inner and outer link channels. \\
Weeds & Soil conservation involving plantation and embankment. \\
& Increase in the salinity level of Chilika by opening the mouth and link channels. \\
& Biological control by introducing carps. \\
Water pollution & Limited use of motor boats \\
& Ban on chemical food mainly used in prawn culture. \\
& Embankment around Chilika. Checking industrial pollution. \\
Prawn culture & Banning of spawn collection. \\
& Involvement of Coast Guards. \\
& Ecological training to the prawn culturists. \\
Increased fishing intensity & Alternative income sources for the locals. \\
& Revitalizing involvement of existing cooperative institutions. \\
& Check on the immigration of refugees. \\
& Check on the use of fine-mesh nets. \\
Encroachment & Survey and resettlement. \\
& Eviction of the encroachers. \\
& Restoring the traditional rights of the locals. \\
\end{tabular}

onstrated that there was no difference in the yields from the two kinds of manure; subsequently, more farmers turned to crop residues as this meant lower labor inputs. As a consequence, kambal is now flourishing in the forest and through careful pruning and good rootsrock, it will grow back to tree size in a few years.

The documentation of natural resources, the history of their use, people's development aspirations, ongoing difficulties in resource management in the form of manifold conflicts, and people's prescriptions on how the resources should be managed are clearly very pertinent inputs for any system of adaptive co-management. The PBR of Berhampur village near Chilika in Orissa furnishes an interesting example of such a product. Chilika, the largest brackish-water lagoon in south and southeast Asia, is under manifold threats. These arise because of the escalating pressures on natural resources: forests in the catchment that have been felled, surrounding fields that are sprayed with pesticides, or fish stocks that are caught in increasing numbers with mechanized boats and fine-meshed nylon nets. It is obviously impractical to think of going back to the old days when most resources were used far less intensively. However it is essential to manage the resources far more carefully.

In this, practical ecologists, such as the fisherfolk of Chilika, can provide valuable inputs, for they are the people with a serious long-term stake in the health of their environment. Table 3 summarizes the management prescriptions flowing from our PBR exercise in Berhampur village.

\section{Benefit Sharing}

The PBR document could also serve a very useful function in implementing article $8(\mathrm{j})$ of the Convention on Biological Diversity (UNEP 1992). This article calls for approval of local people in promoting wider use of their knowledge and sharing with them the benefits of such commercial utilization of knowledge. This is a difficult task, as some of this knowledge is already in the public domain, leaving no bargaining power with the providers. The remaining knowledge is variously distributed across communities and individuals, and is being actively tapped by the researchers and entrepreneurs, often violating the spirit of the CBD provisions (Volker 1997). The issues may be illustrated by a concrete experience in the village Mala from Karnataka, notable for its continuing extensive use of herbal medicine. Mr. Kunjeera Moolya is the most knowledgeable of the dispensers of herbal medicines in Mala; he does not charge for his services, but makes a living as a farm laborer. Moolya was approached in March 1995 by an agent of some pharmaceutical firm to disclose his knowledge of local medicinal plants. He went around the forest for two days and shared this information, for which he was paid a sum of Rs. 220 (U.S. $\$ 6$ ), equivalent to his normal earnings over four to five days. This agent evidently represented some pharmaceutical company engaged in screening Indian plant resources for possible commercial products.

The best organized of such programes is run by Hoechst Marion Roussel India, a subsidiary of a multinational company of German origin (Volker 1997). Hoechst runs a research unit in Mumbai, established in 1972 and described as a target-oriented lead discovery center from natural origin. It employs some 70 Ph.D.-holding scientists, all but the director being Indian citizens. Indigenous information, obtained from people like Moolya, as well as from published literature and modern electronic databases, is used to provide clues to rationalize the search for plants with interesting biological activities. The published literature includes that from the older tradition of Ayurveda and the modern tradition of ethnobotany. In neither of these traditions is there is any detailed, specific acknowledgment, at the level of local knowledgeable individuals, 
of the source of such information. Only three of the scientists employed by the Hoechst Research Centre are engaged in collecting samples of plants, fungi, and microorganisms; others are busy with screening, toxicology, and investigations of chemical modes of action.

Obviously, Hoechst would pay very many people like Moolya small sums like Rs. 220, and then pool together all the information generated with other public knowledge (such as of Ayurveda) and inputs from many scientific disciplines, to eventually develop a small number of products (Sukh Dev 1997). The process may take many years, perhaps decades, and particular pieces of information provided by a specific individual may or may not yield any product. In any case, every product will use many other inputs in its development. It is therefore difficult to design a system of either regulating collection and use of such knowledge, or ensuring payment of royalty to a particular individual in case his/her knowledge provided an important clue. Furthermore, because much of such knowledge is part of shared cultural resources, there are questions of whether it is appropriate to reward any particular individual who may by chance have been the person to communicate a specific piece of information.

Given these complexities, our approach was to put on record only such information as was voluntarily disclosed by people without any persuasion on the part of investigators. Beyond this, other information was maintained off the formal record as claims, for example, that a particular person in village Kigga of Karnataka has an herbal remedy against snakebite. Such broad claims could subsequently be made public and may attract entrepreneurs to directly contact the claimants. The two parties may then negotiate terms under which the information may be revealed. Elsewhere in the world, innovative experiments of recording such exclusive, undisclosed information through various types of contracts are being initiated (Glowka 1998). In Eucador, a project by the Inter-American Development Bank attempts to computerize traditional knowledge, segregated according to communities. The database manager, a local NGO, compares this with the public-domain knowledge listed in the NAPRALERT database housed at University of Chicago, Chicago, Illinois, USA. Knowledge not yet in the public domain is treated as trade secrets, and is transferred to potential users directly by the corresponding community or an intermediary, through agreements. Further, the NAPRALERT information that is unavailable to the people is also repatriated. On the other hand, know-how licenses are negotiated between Aguaruna people from Peru and Searle and Company, the pharmaceutical division of Monsanto, irrespective of whether or not the knowledge was in the public domain. The license brings the Aguaruna collection fees, annual know-how license fees, and milestone payments as the research progresses. The Aguaruna are also trained locally and in the university, are kept informed of the research progress, and retain all the rights to resources as well as the right to terminate the license. The Costa Rica Biodiversity Act also proposes a national registry of traditional knowledge. However, this will be used only to deny intellectual property rights to innovations with similar applications (Dutfield G. personal communication). In this case, the incentive for the people to record their knowledge is not obvious.

Apart from such one-to-one deals involving intellectual property rights, PBRs may also serve as a tool of conserving and respecting folk knowledge, and rewarding through a different route, namely a system of awards linked to the quality of documentation of knowledge through PBRs (Gadgil 1997). The state, international agencies such as UNEP or UNESCO, or private foundations may come forward to periodically reward the communities, in terms of special development grants and social recognition for excellence in documenting such folk knowledge. This would help to conserve such knowledge through creation of more permanent records, as well as to encourage the younger generation to acquire and keep it alive (Anonymous 1996).

\section{Prospects}

The experience of preparing these 52 PBRs has been most positive, with considerable enthusiasm generated among teachers and students in educational institutions, among NGO activists, and among members of local communities. An account of the experience appeared in the Annual Survey of Environment for 1998 published by Hindu, one of the leading English-language newspapers of south India (Gadgil et al. 1998). A large number of people from all over India have expressed an interest in undertaking PBR exercises in their own area, as a result of this exposure. Similar interest has been expressed from Brazil and South Africa as well. More concretely, the government of India, in its draft biodiversity act (Anonymous 1998) tabled in the parliament session during April 1999, has specifically entrusted to the village councils the responsibility of documenting biodiversity resources, knowledge, and conservation efforts. Further, the bill provides for direct sharing of royalties from the commercial application with the individual or group of people only if the exclusiveness of the knowledge or resources that they provided can be ascertained. In all other cases, part of the benefits generated from commercial application of biodiversity and related knowledge would be deposited in a national fund. This national fund would be used primarily for rewarding and encouraging conservation efforts and knowledge contributions. Although the bill does not specifically mention the village documents as the basis for benefit sharing, it would eventually become imperative for the government to 
do so. Interestingly enough, without waiting for the government initiative to take off, the NGO group that coordinated this exercise in the state of Himachal Pradesh is seriously pursuing a follow-up, with many more PBRs being prepared throughout the state, primarily as a tool for adaptive co-management. A similar effort is on in 60 panchayats in the district Ernakulam of Kerala. This would be part of the vigorous attempt to decentralize development planning in the state. Other NGO groups from Karnataka and Andhra Pradesh are also preparing PBRs in several villages, with the expectation that these would also serve to protect people's rights over resources and knowledge. We are attempting to computerize the information contained in PBRs and to develop systems of synthesizing this information at higher spatial scales, such as districts and states. Eventually, the relevant, spatially aggregated information can be fed back to people so that they can benefit from learning about uses, trade value, or conservation efforts in other areas. In the long run, we have every hope that PBRs will evolve into a useful tool supporting a process of community-based management of living resources, contributing to conservation, and the rewarding of folk knowledge.

\section{ACKNOWLEDGMENTS}

People's Biodiversity Registers has been an extensive, cooperative effort; we are therefore grateful for numerous contributions of a very large number of colleagues from academic institutions and NGOs, as well as among the residents of the 52 study sites. It is unfortunately not possible to name all of them individually. K. C. Malhotra, M. K. Prasad, and Darshan Shankar have guided the whole exercise. Shekhar Singh, Ashish Kothari, and Graham Dutfield provided useful suggestions. From the Western Ghats Biodiversity Network, Yogesh Gokhale, K. P. Achar, G. K. Bhat, Winfred Thomas, Parvati Menon, Dayanand Bhat, C. K. Poojari, Prakash Pandit, and K. N. Deviprasad offered many insights. The state-level coordinators in the Biodiversity Conservation Prioritization Project, in particular, D. S. Srivastava, Ajay Mehta, P. C. Bhattacharji, Devashish Kar, Sameer Acharya, and T. S. Channesh and their colleagues, furthered the process. Anirban Ganguly and Smita Botre shared their experiences. Deepak Jain helped with the data compilation. This work has been funded by a long-term grant to the Centre for Ecological Sciences, Indian Institute of Science from the Ministry of Environment and Forests, Government of India, by a Fellowship from the Pew Foundation, and by a grant from WWFIndia from the Biodiversity Support Programme, a USAIDfunded consortium of WWF-USA, World Resources Institute (WRI), and the Nature Conservancy.

\section{Literature Cited}

Anonymous. 1996. Report of the subgroup on biodiversity. Karnataka State Planning Board, Bangalore, India.

Anonymous. 1998. The draft Indian Biological Diversity Act. Ministry of Environment and Forests, Government of India, New Delhi, India.

Chambers, R. 1992. Rural appraisal: rapid, relaxed and participatory (with discussion). Institute of Development Studies, Sussex, UK.

Chambers, R. 1993. Challenging the professions: frontiers for rural development. Intermediate Technology Publications, London, UK.

Chhatre, A., P. R. S. Rao, G. Utkarsh, P. Pramod, A. Ganguly, and M. Gadgil. 1998. Srishtigyaan: a methodology manual for people's biodiversity registers. Centre for Ecological Sciences, Indian Institute of Science, Bangalore, India.

Gadgil, M. 1996. Documenting diversity: an experiment. Current Science 70:(1)36-44.

Gadgil, M. 1997. A framework for managing India's Biodiversity. RIS Biotechnology and Development Review 1: (1) $1-14$.

Gadgil, M., and F. Berkes. 1991. Traditional resource management systems. Resource Management and Optimization 18:(3-4)127-141.

Gadgil, M., F. Berkes, and C. Folke. 1993. Indigenous knowledge for biodiversity conservation. Ambio 22:151-156.

Gadgil, M., M. D. S. Chandran, P. Pramod, G. Utkarsh, Y. Gokhale, W. Thomas, and P. Menon. 1996. People's biodiversity register: a record of India's wealth. Amruth (Oct. 96) Special Supplement: 1-16.

Gadgil, M., and V. M. Meher Homji. 1990. Ecological diversity. Pages 175-198 in J. C. Daniels and J. S. Serrao, editors. Conservation in developing countries: problems and prospects. Proceedings of the Centenary Seminar of the Bombay Natural History Society. Bombay Natural History Society and Oxford University Press, Bombay, India.

Gadgil, M., and P. R. S. Rao. 1995. Designing incentives to conserve India's biodiversity. Pages 53-62 in S. Hanna and M. Munasinghe, editors. Property rights in a social and ecological context. The Beijer International Institute of Ecological Economics, and The World Bank, Washington, D.C., USA.

Gadgil, M., and other colleagues from Srishti Jigyaasa Pariwar. 1998. Where are the people? Hindu Survey of the Environment 1998:107-137.

Glowka, L. 1998. A guide to designing legal frameworks to determine access to genetic resources. IUCN, Gland, Switzerland.

Gokhale, Y., R. Velankar, M. D. S. Chandran, and M. Gadgil. 1998. Sacred woods, grasslands and waterbodies as selforganized systems of conservation. Pages 366-396 in P. S. Ramakrishnan, K. G. Saxena, and U. M. Chandrashekara, editors. Conserving the sacred for biodiversity management, Oxford and IBH Publishing, New Delhi, India.

Martin, G. J. 1995. Ethnobotany: A methods manual. Chapman and Hall, London, UK.

Ostrom, E. 1990. Governing the commons: the evolution of institutions for collective action. Cambridge University Press, New York, New York, USA.

Ostrom, E. 1992. Crafting Institutions for self governing irrigation systems. Institute for Contemporary Studies, San Fransisco, California.

Posey, D. A., and G. Dutfield. 1996. Beyond intellectual property: towards traditional resource rights for indigenous people and local communities. International Development Research Centre, Ottawa, Canada.

Reid, W. V., S. A. Laird, R. Gamez, A. Sittenfeld, D. H. Janzen, M. A. Gollin, and C. Juma. 1993. Biodiversity prospecting: using genetic resources for sustainable development. World Resource Institute, Washington, D.C., USA.

Singh, K. 1994. Managing common pool resources. Oxford University Press, New Delhi, India.

Sukh Dev, 1997. Ethnotherapeutics and modern drug development: the potential of Ayurveda. Current Science 73: (11)909-928.

UNEP. 1992. Convention on biological diversity. United Nations Environment Programme, Nairobi, Kenya.

Volker, H. 1997. Does CBD matter? A case study of Hoechst research centre in India. Biotechnology and Development Review I:(I)34-41.

Walters, C. J., and R. Hilborn. 1976. Adaptive control of fishing systems. Journal of the Fisheries Research Board, Canada 33:145-159. 